\title{
Paenibacillus sonchi sp. nov., a nitrogen-fixing species isolated from the rhizosphere of Sonchus oleraceus
}

\author{
Yuan-Yuan Hong, ${ }^{1}$ Yu-Chao Ma, ${ }^{1}$ Yu-Guang Zhou, ${ }^{2}$ Fei Gao, ${ }^{3}$ \\ Hong-Can Liu ${ }^{2}$ and San-Feng Chen ${ }^{1}$
}

Correspondence

San-feng Chen

chensf@cau.edu.cn

\author{
${ }^{1}$ The State Key Laboratory for Agrobiotechnology, China Agricultural University, Beijing 100094, \\ PR China \\ ${ }^{2}$ China General Microbiological Culture Collection Center, Institute of Microbiology, Chinese \\ Academy of Sciences, Datun Road, Chaoyang District, Beijing 100101, PR China \\ ${ }^{3}$ College of Biological Sciences, China Agricultural University, Beijing 100094, PR China
}

The genus Paenibacillus was described by Ash et al. (1993) on the basis of analysis of the 16S rRNA gene sequences of group 3 bacilli. Members of the genus are widely distributed in nature and have physiologically diverse characteristics. Some species consistently show a great capacity to fix atmospheric nitrogen in vitro (Berge et al., 2002; Ma et al., 2007a, b; Ding et al., 2005; Elo et al., 2001). Here we show that a bacterial strain, designated X19-5 ${ }^{\mathrm{T}}$, isolated from rhizosphere soil of Sonchus oleraceus represents a novel nitrogen-fixing species of the genus Paenibacillus.

Strain X19-5 ${ }^{\mathrm{T}}$ was isolated from rhizosphere soil of Sonchus oleraceus by screening on nitrogen-free medium (Ma et al., 2007a). The nitrogen-free medium comprised (per litre water): $20 \mathrm{~g}$ sucrose, $0.1 \mathrm{~g} \mathrm{~K}_{2} \mathrm{HPO}_{4}, 0.4 \mathrm{~g} \mathrm{KH}_{2} \mathrm{PO}_{4}, 0.2 \mathrm{~g}$ $\mathrm{MgSO}_{4} \cdot 7 \mathrm{H}_{2} \mathrm{O}, 0.1 \mathrm{~g} \mathrm{NaCl}, 0.01 \mathrm{~g} \mathrm{FeCl}_{3}$ and $0.002 \mathrm{~g}$ $\mathrm{Na}_{2} \mathrm{MoO}_{4}$. One gram of soil was placed in $9 \mathrm{ml}$ sterile water and stirred for $50 \mathrm{~min}$. Aqueous volumes $(100 \mu \mathrm{l}$ of the mixture) were heated at $80{ }^{\circ} \mathrm{C}$ for $10 \mathrm{~min}$ and then

The GenBank/EMBL/DDBJ accession numbers for the nifH and $16 \mathrm{~S}$ rRNA gene sequences of strain $\times 19-5^{\top}$ are EU867444 and D0358736, respectively.

An extended neighbour-joining phylogenetic tree of representatives of the genus Paenibacillus based on 16S rRNA gene sequences is available as supplementary material with the online version of this paper. spread on nitrogen-free medium in triplicate and incubated at $30{ }^{\circ} \mathrm{C}$. After 3 days incubation, strain $\mathrm{X} 19-5^{\mathrm{T}}$ was selected for further study.

To confirm the nitrogen-fixing capacity of strain X19-5 ${ }^{\mathrm{T}}$, an assay for nitrogenase activity and PCR amplification of the nifH gene were carried out. For measurement of nitrogenase activity, strain $\mathrm{X} 19-5^{\mathrm{T}}$ and several reference strains were grown on solid RCV mineral medium containing $0.5 \%$ glucose, malate, starch and mannitol (Weaver et al., 1975). After $48 \mathrm{~h}$ at $30^{\circ} \mathrm{C}$, strains were incubated under $2 \%(\mathrm{v} / \mathrm{v})$ acetylene in air for $2 \mathrm{~h}$ and then analysed for ethylene production by using gas chromatography (Berge et al., 2002). As shown in Table 1, strain $\mathrm{X} 19-5^{\mathrm{T}}$ exhibited nitrogenase activity.

Whole-cell DNA for PCR amplification was extracted according to standard methods (Sambrook et al., 1989). A $324 \mathrm{bp}$ fragment of the nifH gene was amplified by using two degenerate primers for the nitrogenase Fe protein gene and then sequenced as described by Ding et al. (2005). Phylogenetic trees were inferred using the neighbourjoining and maximum-parsimony methods in the software package MEGA3.1 (Kumar et al., 2004). As no significant differences were found among the phylogenetic trees obtained by the different methods used, only the trees constructed by using the neighbour-joining method are 
Table 1. Nitrogenase activity of strain $X 19-5^{\top}$ ( $P$. sonchi sp. nov.) compared with some nitrogen-fixing species of the genus Paenibacillus

Results are means \pm SD of three determinations.

\begin{tabular}{|lc|}
\hline Strain & $\begin{array}{c}\text { Nitrogenase activity } \\
\text { [nmol } \mathbf{C}_{\mathbf{2}} \mathbf{H}_{\mathbf{2}} \text { (mg protein) }^{-\mathbf{1}} \text { ] }\end{array}$ \\
\hline P. azotofixans ATCC $35681^{\mathrm{T}}$ & $2256.8 \pm 46.9$ \\
P. polymyxa ATCC $842^{\mathrm{T}}$ & $3.2 \pm 0.55$ \\
P. macerans ATCC $8244^{\mathrm{T}}$ & $2.48 \pm 0.2$ \\
P. odorifer TOD $45^{\mathrm{T}}$ & $37.62 \pm 18.9$ \\
P. graminis RSA19 & $272.9 \pm 7.9$ \\
P. sabinae DSM $17841^{\mathrm{T}}$ & $3885.9 \pm 72.9$ \\
P. zanthoxyli DSM $18202^{\mathrm{T}}$ & $6282.4 \pm 107.97$ \\
Strain X19-5 & $129.8 \pm 82.2$ \\
\hline
\end{tabular}

shown. Phylogenetic analysis based on nifH gene sequences revealed that strain X19-5 ${ }^{\mathrm{T}}$ clustered with species of the genus Paenibacillus (Fig. 1). Levels of nifH gene sequence similarity between strain X19-5 $5^{\mathrm{T}}$ and Paenibacillus zanthoxyli DSM $18202^{\mathrm{T}}$, Paenibacillus azotofixans ATCC $35681^{\mathrm{T}}$, Paenibacillus forsythiae DSM $17842^{\mathrm{T}}$, Paenibacillus graminis RSA $19^{\mathrm{T}}$, Paenibacillus macerans ATCC $8244^{\mathrm{T}}$, Paenibacillus odorifer TOD $45^{\mathrm{T}}$, Paenibacillus polymyxa DSM $36^{\mathrm{T}}$ and Paenibacillus sabinae DSM $17841^{\mathrm{T}}$ were 97.6, 97.6, 97.5, 98.1, 98.1, 98.4, 98.1 and $97.5 \%$, respectively.
A nearly complete sequence of the 16S rRNA gene (1500 bp) was obtained from a PCR product amplified from strain X19- $5^{\mathrm{T}}$ by using the universal forward primer $\mathrm{P} 1$ and the universal reverse primer P6. Primer P1 (5'AGAGTTTGATCCTGGTCAGAACGCT-3') corresponds to positions 8-37 and primer P6 (5'-TACGGCTACCTTGTTACGACTTCACCCC-3') corresponds to positions 1479-1506 in the Escherichia coli 16S rRNA gene (Yanagi \& Yamasato, 1993). The amplified 16S rRNA gene was sequenced by using an $\mathrm{ABI} 377$ automatic sequencer (Applied Biosystems). Comparison of the 16S rRNA gene sequence of strain X19-5 $5^{\mathrm{T}}$ with sequences held in GenBank revealed that this organism clustered with species of the genus Paenibacillus. The 16S rRNA gene sequence of strain $\mathrm{X} 19-5^{\mathrm{T}}$ was aligned with sequences of recognized species of the genus Paenibacillus by using the software package MEGA3.1. (Fig. 2; an extended version of this tree is available as Supplementary Fig. S1, in IJSEM Online). Strain X19-5 ${ }^{\mathrm{T}}$ showed the highest $16 \mathrm{~S}$ rRNA gene sequence similarity with P. graminis RSA $19^{\mathrm{T}}(98.8 \%)$. Levels of $16 \mathrm{~S}$ rRNA gene sequence similarity between strain X19-5 ${ }^{\mathrm{T}}$ and other recognized members of the genus Paenibacillus were below $97 \%$.

Strain $\mathrm{X} 19-5^{\mathrm{T}}$ was tested for a range of phenotypic, physiological and biochemical characteristics together with the type strains of closely related Paenibacillus species, including P. azotofixans ATCC $35681^{\mathrm{T}}$, P. odorifer TOD $45^{\mathrm{T}}$,

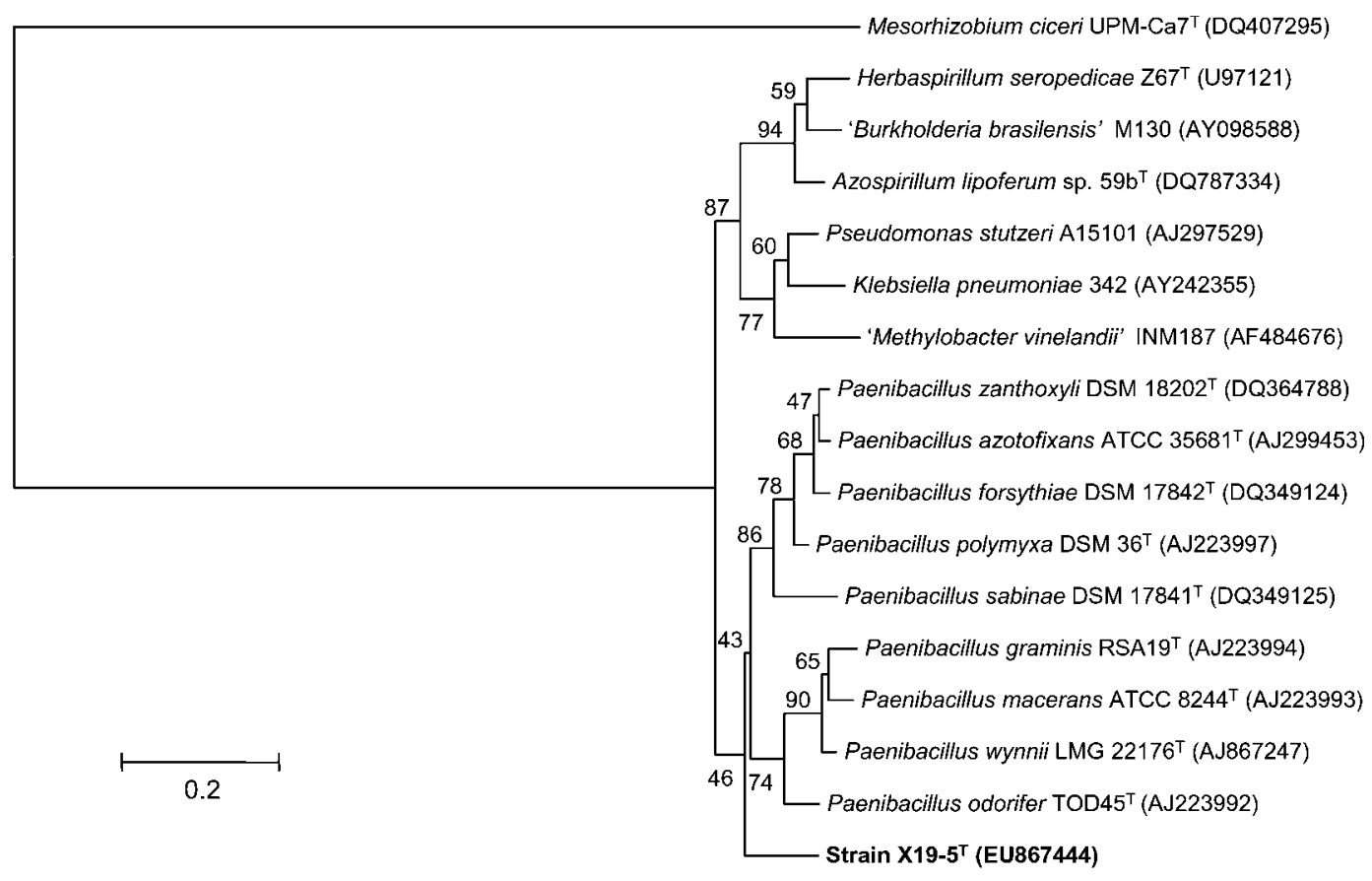

Fig. 1. Phylogenetic tree based on partial nifH gene sequence comparison (324 nt fragment) obtained using the neighbourjoining method, showing the position of strain $X 19-5^{\top}$ among species of the genus Paenibacillus. The sequence of Mesorhizobium ciceri was used as an outgroup. Numbers at nodes are percentage bootstrap values based on 1000 resamplings. Bar, 0.2 substitutions per nucleotide position. 


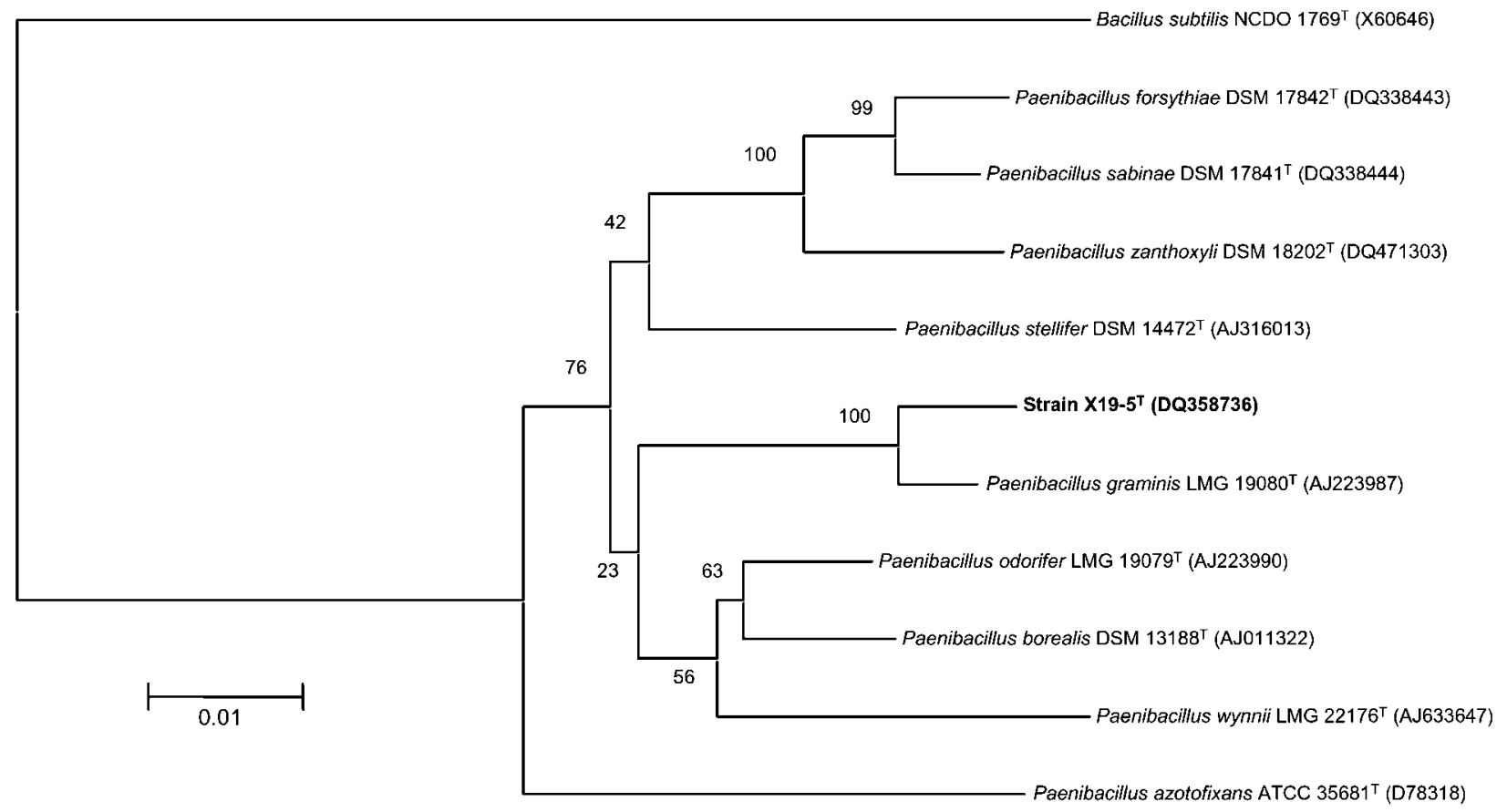

Fig. 2. Neighbour-joining phylogenetic tree based on $16 \mathrm{~S}$ rRNA gene sequences showing the position of strain $X 19-5^{\top}$ among species of the genus Paenibacillus. The sequence of Bacillus subtilis NCDO $1769^{\top}$ was used as an outgroup. Numbers at nodes are percentage bootstrap values based on 1000 resamplings. Bar, 0.01 substitutions per nucleotide position. An extended version of the tree including all recognized species of Paenibacillus is available as Supplementary Fig. S1 (in IJSEM Online).

P. forsythiae DSM $17842^{\mathrm{T}}$, P. zanthoxyli DSM $18202^{\mathrm{T}}, P$. sabinae DSM $17841^{\mathrm{T}}, P$. graminis $\mathrm{RSA} 19^{\mathrm{T}}$ and $P$. stellifer DSM $14472^{\mathrm{T}}$, as reference strains. For observation of cell morphology, strain $\mathrm{X} 19-5^{\mathrm{T}}$ was grown in endosporeforming medium $[0.07 \%$ yeast extract, $0.1 \%$ tryptone, $0.1 \%$ glucose, $0.02 \%\left(\mathrm{NH}_{4}\right)_{2} \mathrm{SO}_{4}, 0.02 \% \mathrm{MgSO}_{4} .7 \mathrm{H}_{2} \mathrm{O}$ and $0.1 \% \mathrm{~K}_{2} \mathrm{HPO}_{4}, \mathrm{pH} 7.2$ ] for $72 \mathrm{~h}$, and the cells were then examined by light microscopy. Strain X19-5 $5^{\mathrm{T}}$ formed ellipsoidal spores, located centrally or subterminally in swollen sporangia. Colonies on LD medium [per litre water: $10 \mathrm{~g}$ tryptone, $5 \mathrm{~g}$ yeast extract, $2.5 \mathrm{~g} \mathrm{NaCl}, \mathrm{pH} 7.0$ ] agar were circular, convex and glossy with entire margins after $72 \mathrm{~h}$ incubation. Gram-staining demonstrated that cells of strain $\mathrm{X} 19-5^{\mathrm{T}}$ were Gram-positive rods. Cell motility was determined by using two methods, i.e. directly by light microscopy and observation of growth spread of cells in test tubes containing semisolid LD medium after 3 days incubation. Cells of strain $\mathrm{X} 19-5^{\mathrm{T}}$ were motile. To determine aerotactic ability, bacterial cells were inoculated by mixing them with semisolid medium at $40-50{ }^{\circ} \mathrm{C}$ in test tubes followed by growth at $30{ }^{\circ} \mathrm{C}$ for 3 days. Although cells of strain X19-5 $5^{\mathrm{T}}$ grew throughout the medium in test tubes, cells near the surface grew better than those near the bottom, suggesting that strain $\mathrm{X} 19-5^{\mathrm{T}}$ was aerobic.

Most physiological and biochemical tests, including Gram staining, nitrate reduction, production of dextrin, temperature and $\mathrm{pH}$ optima for growth, activities of catalase and oxidase and the Voges-Proskauer reaction, and growth inhibition by $\mathrm{NaCl}$ and lysozyme, were performed according to Gordon et al. (1973), Priest et al. (1981) and Rhodes-Roberts (1981). Hydrolysis of casein and starch was determined as described by Cowan \& Steel (1965). Utilization of various substrates as carbon and energy sources was determined as described by Shirling \& Gottlieb (1966). Differential physiological and biochemical characteristics of strain X19-5 ${ }^{\mathrm{T}}$ and those of the type strains of closely related Paenibacillus species are given in Table 2. Strain X19-5 $5^{\mathrm{T}}$ had physiological properties that allowed its distinction from recognized Paenibacillus species.

The DNA G $+\mathrm{C}$ content was determined by using the method of Tamaoka \& Komagata (1984). The DNA G +C content of strain $\mathrm{X} 19-5^{\mathrm{T}}$ was $46.8 \mathrm{~mol} \%$ (Table 2), within the range of values for recognized Paenibacillus species (Shida et al., 1997).

For DNA-DNA hybridization experiments, total genomic DNA was extracted and purified according to the method described by Yoon et al. (1996) with some modifications. DNA-DNA hybridization was performed according to the method of Ziemke et al. (1998). The level of DNA-DNA relatedness between strain X19-5 ${ }^{\mathrm{T}}$ and $P$. graminis RSA $19^{\mathrm{T}}$ was $45.7 \%$. According to the recommendations of the ad hoc committee, strain X19-5 $5^{\mathrm{T}}$ and P. graminis RSA $19^{\mathrm{T}}$ did not belong to the same species as the value found for 
Table 2. Differential phenotypic characteristics between strain $X 19-5^{\top}$ and the type strains of selected Paenibacillus species

Strains: 1 , X19-5 $5^{\mathrm{T}}$ (P. sonchi sp. nov.); 2, P. azotofixans ATCC $35681^{\mathrm{T}}$ (data from Ma et al., 2008); 3, P. odorifer TOD45 ${ }^{\mathrm{T}}$ (von der Weid et al., 2002); 4, P. graminis RSA $19^{\mathrm{T}}$ (von der Weid et al., 2002); 5, P. stellifer DSM 14472 ${ }^{\mathrm{T}}$ (Suominen et al., 2003); 6, P. forsythiae DSM 17842 ${ }^{\mathrm{T}}$ (Ma \& Chen, 2008); 7, P. sabinae DSM $17841^{\mathrm{T}}$ (Ma et al., 2007a); 8, P. zanthoxyli DSM $18202^{\mathrm{T}}$ (Ma et al., 2007b). +, Positive reaction; -, negative reaction; ND, not determined.

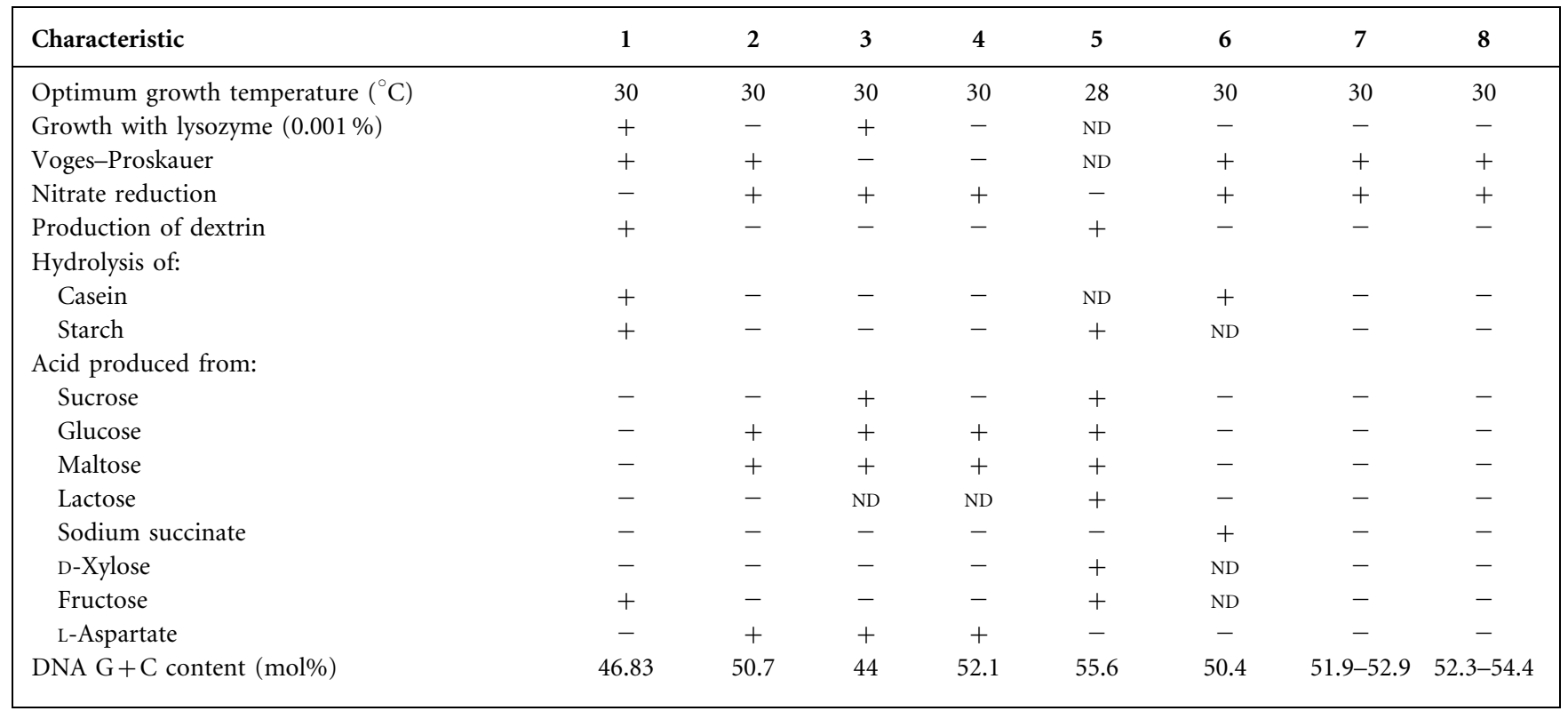

DNA-DNA relatedness was lower that the threshold value of $70 \%$ (Wayne et al., 1987).

For the determination of its cellular fatty acid composition, strain $\mathrm{X} 19-5^{\mathrm{T}}$ was grown in $\mathrm{LD}$ medium at $30{ }^{\circ} \mathrm{C}$ for
3 days. Analysis was carried out as described by Komagata \& Suzuki (1987) by using the Sherlock Identification System (MIDI) (Sasser et al., 2005). Profiles of the major fatty acids of strain X19-5 $5^{\mathrm{T}}$ and the type strains of closely related Paenibacillus species are shown in Table 3. Anteiso-

Table 3. Cellular fatty acid profiles of strain $X 19-5^{\top}$ and closely related Paenibacillus type strains

Strains: 1, X19-5 ${ }^{\mathrm{T}}$ (P. sonchi sp. nov.); 2, P. graminis RSA19 ${ }^{\mathrm{T}}$ (data from von der Weid et al., 2002); 3, P. borealis DSM $13188^{\mathrm{T}}$ (data from Elo et al., 2001); 4, P. stellifer DSM $14472^{\mathrm{T}}$ (Suominen et al., 2003); 5, P. azotofixans ATCC $35681^{\mathrm{T}}$ (Yoon et al., 2003); 6, P. zanthoxyli DSM 18202 ${ }^{\mathrm{T}}$ (Ma et al., 2007b); 7, P. forsythiae DSM $17842^{\mathrm{T}}$ (Ma \& Chen, 2008); 8, P. sabinae DSM $17841^{\mathrm{T}}$ (Ma et al., 2007a). Data are percentages of the total fatty acids. NR, Not reported. For unsaturated fatty acids, the position of the double bond can be located by counting from the methyl $(\omega)$ end of the carbon chain; cis isomers are indicated by the suffix $c$.

\begin{tabular}{|c|c|c|c|c|c|c|c|c|}
\hline Fatty acid & 1 & 2 & 3 & 4 & 5 & 6 & 7 & 8 \\
\hline \multicolumn{9}{|c|}{ Saturated straight-chain } \\
\hline $\mathrm{C}_{14: 0}$ & 4.31 & 3.69 & 18.6 & 0.7 & 5.0 & 4.87 & 4.85 & 2.96 \\
\hline $\mathrm{C}_{18: 0}$ & 1.28 & 2.36 & NR & 1.1 & 0.3 & 6.74 & 5.64 & 3.28 \\
\hline \multicolumn{9}{|c|}{ Saturated iso-branched } \\
\hline iso- $\mathrm{C}_{14: 0}$ & 9.80 & 12.20 & 4.9 & 0.6 & 4.7 & 3.99 & 2.64 & 3.20 \\
\hline iso- $\mathrm{C}_{16: 0}$ & 15.85 & 13.42 & 10.5 & 7.7 & 5.3 & 14.85 & 11.48 & 14.40 \\
\hline iso- $\mathrm{C}_{17: 0}$ & 0.64 & 0.53 & 4.90 & 7.0 & 1.1 & 0.61 & 0.98 & 0.79 \\
\hline \multicolumn{9}{|c|}{ Saturated anteiso-branched } \\
\hline anteiso- $\mathrm{C}_{15: 0}$ & 39.36 & 42.00 & 35.2 & 49.9 & 45.4 & 32.19 & 29.87 & 36.59 \\
\hline anteiso- $\mathrm{C}_{17: 0}$ & 2.01 & 1.45 & 2.1 & 16.7 & 2.1 & 3.89 & 4.52 & 6.38 \\
\hline \multicolumn{9}{|l|}{ Unsaturated } \\
\hline
\end{tabular}


$\mathrm{C}_{15: 0}$, the major fatty acid in recognized members of the genus Paenibacillus, was also the major fatty acid component of strain X19-5 ${ }^{\mathrm{T}}(39.3 \%)$.

In summary, phylogenetic analysis based on the full-length 16S rRNA gene sequence and a fragment of the nifH gene sequence, DNA G+C content and chemotaxonomic properties revealed that strain $\mathrm{X} 19-5^{\mathrm{T}}$ was a member of the genus Paenibacillus. Several phenotypic characteristics and levels of DNA-DNA hybridization further demonstrated that our isolate represents a novel species of the genus Paenibacillus, for which the name Paenibacillus sonchi sp. nov. is proposed, strain $\mathrm{X} 19-5^{\mathrm{T}}$ being the type strain.

\section{Description of Paenibacillus sonchi sp. nov.}

Paenibacillus sonchi (son' chi. L. n. sonchus $-i$, the herb sowthistle, and also a botanical genus name; L. gen. n. sonchi of Sonchus, referring to the plant Sonchus oleraceus, the source of the rhizosphere soil from which the type strain was isolated).

Gram-positive, aerobic, motile, straight rods $(0.5 \times 5 \mu \mathrm{m})$. Ellipsoidal spores are located centrally or subterminally in swollen sporangia. Colonies on LD medium are circular, convex and glossy with entire margins after incubation for $72 \mathrm{~h}$ at $30{ }^{\circ} \mathrm{C}$. Temperature range for growth is $10-40{ }^{\circ} \mathrm{C}$, with optimum growth at $30{ }^{\circ} \mathrm{C}$. Optimum $\mathrm{pH}$ is 7.0-7.2. Grows in the absence of $\mathrm{NaCl}$ and in $3 \%(\mathrm{w} / \mathrm{v}) \mathrm{NaCl}$, but is unable to tolerate $5 \% \mathrm{NaCl}$. Growth is not inhibited by $0.001 \%(\mathrm{w} / \mathrm{v})$ lysozyme. Catalase-negative and oxidasenegative. Positive for the Voges-Proskauer reaction. Nitrate is not reduced to nitrite. Nitrogen is fixed. Able to utilize fructose to produce acid, but not glucose, sucrose, lactose, succinate, D-xylose, maltose or L-aspartate. Casein and starch are hydrolysed. The $\mathrm{G}+\mathrm{C}$ content of the DNA of the type strain is $46.8 \mathrm{~mol} \%$ (thermal denaturation method).

The type strain, X19-5 $5^{\mathrm{T}}\left(=\mathrm{CCBAU} 83901^{\mathrm{T}}=\mathrm{LMG} 24727^{\mathrm{T}}\right)$, was isolated from rhizosphere soil of Sonchus oleraceus in Xinjiang, China.

\section{Acknowledgements}

This work was supported by the National Natural Science Foundation of China (Grant No. 30470028).

\section{References}

Ash, C., Priest, F. G. \& Collins, M. D. (1993). Molecular identification of rRNA group 3 bacilli (Ash, Farrow, Wallbanks and Collins) using a PCR probe test. Proposal for the creation of a new genus Paenibacillus. Antonie Van Leeuwenhoek 64, 253-260.

Berge, O., Guinebretiere, M. H., Achouak, W., Normand, P. \& Heulin, T. (2002). Paenibacillus graminis sp. nov. and Paenibacillus odorifer sp. nov., isolated from plant roots, soil and food. Int J Syst Evol Microbiol 52, 607-616.

Cowan, S. T. \& Steel, K. J. (1965). Manual for the Identification of Medical Bacteria. London: Cambridge University Press.
Ding, Y., Wang, J., Liu, Y. \& Chen, S. (2005). Isolation and identification of nitrogen-fixing bacilli from plant rhizospheres in Beijing region. J Appl Microbiol 99, 1271-1281.

Elo, S., Suominen, I., Kampfer, P., Juhanoja, J., Salkinoja-Salonen, M. \& Haahtela, K. (2001). Paenibacillus borealis sp. nov., a nitrogen-fixing species isolated from spruce forest humus in Finland. Int J Syst Evol Microbiol 51, 535-545.

Gordon, R. E., Haynes, W. C. \& Pang, C. H.-N. (1973). The Genus Bacillus. US Department of Agriculture Handbook no. 427. Washington, DC: Agricultural Research Service.

Komagata, K. \& Suzuki, K. (1987). Lipid and cell-wall analysis in bacterial systematics. Methods Microbiol 19, 161-207.

Kumar, S., Tamura, K. \& Nei, M. (2004). MEGA3: integrated software for Molecular Evolutionary Genetics Analysis and sequence alignment. Brief Bioinform 5, 150-163.

Ma, Y. C. \& Chen, S. F. (2008). Paenibacillus forsythiae sp. nov., a nitrogen-fixing species isolated from rhizosphere soil of Forsythia mira. Int J Syst Evol Microbiol 58, 319-323.

Ma, Y., Xia, Z., Liu, X. \& Chen, S. (2007a). Paenibacillus sabinae sp. nov., a nitrogen-fixing species isolated from the rhizosphere soils of shrubs. Int J Syst Evol Microbiol 57, 6-11.

Ma, Y., Zhang, J. \& Chen, S. (2007b). Paenibacillus zanthoxyli sp. nov., a novel nitrogen-fixing species isolated from the rhizosphere of Zanthoxyli simulans. Int J Syst Evol Microbiol 57, 873-877.

Priest, F. G., Goodfellow, M. \& Todd, C. (1981). The genus Bacillus: a numerical analysis. In The Aerobic Endospore-Forming Bacteria. Classification and Identification, pp. 91-103. Edited by R. C. W. Berkeley \& M. Goodfellow. London: Academic Press.

Rhodes-Roberts, M. (1981). The taxonomy of some nitrogen-fixing Bacillus species with special reference to nitrogen fixation. In The Aerobic Endospore-Forming Bacteria. Classification and Identification, pp. 315-335. Edited by R. C. W. Berkeley \& M. Goodfellow. London: Academic Press.

Sambrook, J., Fritsch, E. F. \& Maniatis, T. (1989). Molecular Cloning: a Laboratory Manual, 2nd edn. Cold Spring Harbor, NY: Cold Spring Harbor Laboratory.

Sasser, M., Kunitsky, C., Jackoway, G., Ezzell, J. W., Teska, J. D., Harper, B., Parker, S., Barden, D., Blair, H. \& other authors (2005). Identification of Bacillus anthracis from culture using gas chromatographic analysis of fatty acid methyl esters. J AOAC Int 88, 178-181.

Shida, O., Takagi, H., Kadowaki, K., Nakamura, L. K. \& Komagata, K. (1997). Transfer of Bacillus alginolyticus, Bacillus chondroitinus, Bacillus curdlanolyticus, Bacillus glucanolyticus, Bacillus kobensis, and Bacillus thiaminolyticus to the genus Paenibacillus and emended description of the genus Paenibacillus. Int J Syst Bacteriol 47, 289-298.

Shirling, E. B. \& Gottlieb, D. (1966). Methods for characterization of Streptomyces species. Int J Syst Bacteriol 16, 313-340.

Suominen, I., Spröer, C., Kämpfer, P., Rainey, F. A., Lounatmaa, K. \& Salkinoja-Salonen, M. (2003). Paenibacillus stellifer sp. nov., a cyclodextrin-producing species isolated from paperboard. Int J Syst Evol Microbiol 53, 1369-1374.

Tamaoka, J. \& Komagata, K. (1984). Determination of DNA base composition by reversed-phase high-performance liquid chromatography. FEMS Microbiol Lett 25, 125-128.

von der Weid, I., Frois Duarte, G., van Elsas, J. D. \& Seldin, L. (2002). Paenibacillus brasilensis sp. nov., a novel nitrogen-fixing species isolated from the maize rhizosphere in Brazil. Int J Syst Evol Microbiol 52, 2147-2153.

Wayne, L. G., Brenner, D. J., Colwell, R. R., Grimont, P. A. D., Kandler, O., Krichevsky, M. I., Moore, L. H., Moore, W. E. C., Murray, R. G. E. \& other authors (1987). International Committee on Systematic Bacteriology. 
Report of the ad hoc committee on reconciliation of approaches to bacterial systematics. Int J Syst Bacteriol 37, 463-464.

Weaver, P. F., Wall, J. D. \& Gest, H. (1975). Characterization of Rhodopseudomonas capsulata. Arch Microbiol 105, 207-216.

Yanagi, M. \& Yamasato, K. (1993). Phylogenetic analysis of the family Rhizobiaceae and related bacteria by sequencing of $16 \mathrm{~S}$ rRNA gene using PCR and DNA sequencer. FEMS Microbiol Lett 107, 115-120.

Yoon, J.-H., Kim, H., Kim, S.-B., Kim, H.-J., Kim, W. Y., Lee, S. T., Goodfellow, M. \& Park, Y.-H. (1996). Identification of
Saccharomonospora strains by the use of genomic DNA fragments and rRNA gene probes. Int J Syst Bacteriol 46, 502-505.

Yoon, J. H., Oh, H. M., Yoon, B. D., Kang, K. H. \& Park, Y. H. (2003). Paenibacillus kribbensis sp. nov. and Paenibacillus terrae sp. nov., bioflocculants for efficient harvesting of algal cells. Int J Syst Evol Microbiol 53, 295-301.

Ziemke, F., Höfle, M. G., Lalucat, J. \& Rosselló-Mora, R. (1998). Reclassification of Shewanella putrefaciens Owen's genomic group II as Shewanella baltica sp. nov. Int J Syst Bacteriol 48, 179-186. 